\title{
Pengaruh Pemberian Silika dan Mangan Terhadap Mutu Fisiologis Benih Padi (Oryza sativa L.) yang Dihasilkan
}

\author{
Effect of Silica and Manganese on Physiological Quality of Rice Seed \\ (Oryza sativa L.) Produced
}

\author{
Agustiansyah $^{1} *$ \\ ${ }^{1}$ Jurusan Agronomi dan Hortikultura, Fakultas Pertanian, Universitas Lampung \\ Jl. Prof. Soemantri Brodjonegoro, No 1 Bandar Lampung, Indonesia 35145 \\ Email:agustiansyah.1972@fp.unila.ac.id
}

Diterima 11 Januari 2017/ Disetujui 11 Maret 2017

\begin{abstract}
This study aims to determine the response of rice crop on seed physiological quality of the administration of silica and manganese. This experiment was conducted in greenhouse of Faculty of Agriculture, University of Lampung from June 2013 until September 2013. The experiments were conducted in a perfect randomized block design that was repeated three times. The design of treatment arranged in a factorial (5x2). The first factor is the provision of silica (Si), which consists of 5 degree of concentration, ie 0; 5; 100; 150; 200 ppm. The second factor is the provision of Manganese (Mn) with a concentration of 0 ppm (MnO) and $5 \mathrm{ppm}(\mathrm{Mnl})$. Based on the results of the study concluded that increasing the concentration to $200 \mathrm{ppm}$ Si accompanied by administration of $5 \mathrm{ppm} \mathrm{Mn}$ can improve the quality of the plant physiological variables germination, growing simultaneity, and normal seedling dry weight.
\end{abstract}

Keywords: seed, manganese, quality, silica, rice

\section{ABSTRAK}

Penelitian ini bertujuan untuk mengetahui tanggapan tanaman padi pada mutufisiologis benih terhadap pemberian Silika dan Mangan. Percobaan ini dilaksanakan di Rumah Kaca Fakultas Pertanian Universitas Lampung dari bulan Juni 2013 sampai dengan September 2013. Percobaan dilakukan dalam Rancangan Acak Kelompok Teracak Sempurna diulang tiga kali. Rancangan perlakukan disusun secara faktorial (5x2). Faktor pertama adalah pemberian Silika (Si) yang terdiri dari 5 taraf konsentrasi, yaitu 0;5; 100;150; 200 ppm. Faktor kedua adalah pemberian Mangan (Mn) dengan konsentrasi 0 ppm $\left(\mathrm{Mn}_{0}\right)$ dan 5 ppm $\left(\mathrm{Mn}_{1}\right)$. Berdasarkan hasil penelitian disimpulkan bahwa peningkatan konsentrasi Si sampai 200 ppm yang disertai dengan pemberian Mnsebesar 5 ppm mampu meningkatkan mutu fisiologis tanaman pada variable daya berkecambah, keserempakan tumbuh, dan bobot kering kecambah normal.

Kata kunci: benih, mangan, mutu, padi, silika.

\section{PENDAHULUAN}

Produktivitas padi di Indonesia saat ini belum optimal. Rata-rata produktivitas padi di Indonesia saat ini \pm 5, 3 ton/ha (Badan Pusat Statistik 2016), sedangkan potensi produktivitas varietas padi unggul dapat mencapai rata rata 5-9,3 ton/ha (Balai Besar Penelitian Tanaman Padi, 2016). Salah satu upaya untuk meningkatkan produkstivitas padi adalah dengan menggunakan benih bermutu tinggi dari varietas unggul, khususnya mutu fisiologis benih. Benih padi dengan mutu fisiologi tinggi dihasilkan melalui pemupukan yang tepat baik waktu dan dosis, terutama unsur hara makro seperti nitrogen, fosfat, dan kalium. Selain unsur hara makro, terdapat beberapa unsur hara lainnya, seperti silika ( $\mathrm{Si}$ ) yang juga penting bagi tanaman padi (Yukamgo dan Yuwono, 2007). Pemberian silika dapat meningkatkan berat kering berangkasan jerami dan jumlah gabah (Ma et al.,1989),

memperbaiki ketersediaan $\mathrm{P}$ pada tanaman yang defisien $\mathrm{P}$, atau mengurangi penyerapan $\mathrm{P}$ ketika $\mathrm{P}$ tinggi (Ma et al., 1990), silika mengurangi jumlah gabah hampa per malai dan meningkatkan berat gabah (Mauad et al., 2003), meningkatkan resistensi tanaman terhadap penyakit (Ranganathan et al. , 2006).

Selain $\mathrm{Si}$, unsur hara mikro esensial, seperti $\mathrm{Mn}$ juga penting bagi pertumbuhan tanaman padi. Mangan berperan dalam proses fisiologi tanaman sebagai aktivator beberapa enzim dan katalisator pemecahan molekul air pada proses fotosintesis (Humphrise, 2006; Aref, 2012). Mangan juga memegang peranan penting dalam mempertahankan kondisi hijau daun pada daun yang sudah tua sehingga diharapkan masih dapat berfotosintesis 
(Agustina, 2011).Penelitian ini bertujuan untuk mengetahui tanggapan tanaman padi pada mutu fisiologis benih terhadap pemberian silika dan mangan yang berbeda.

\section{BAHAN DAN METODE}

\section{Tempat, Waktu Penelitian, dan Rancangan Percoban dan Perlakuan}

Percobaan ini dilaksanakan di Rumah Kaca Fakultas Pertanian Universitas Lampung dari bulan Juni 2013 sampai dengan September 2013. Percobaan dilakukan dalam Rancangan Acak Kelompok Teracak Sempurna diulang tiga kali. Rancangan perlakukan disusun secara faktorial $(5 \times 2)$. Faktor pertama adalah pemberian Si yang terdiri dari 5 taraf konsentrasi, yaitu $0 \mathrm{ppm}\left(\mathrm{Si}_{0}\right), 50 \mathrm{ppm}\left(\mathrm{Si}_{1}\right), 100 \mathrm{ppm}\left(\mathrm{Si}_{2}\right)$, $150 \mathrm{ppm}\left(\mathrm{Si}_{3}\right)$, dan $200 \mathrm{ppm}\left(\mathrm{Si}_{4}\right)$. Faktor kedua adalah pemberian $\mathrm{Mn}$ dengan konsentrasi 0 ppm $\left(\mathrm{Mn}_{0}\right)$ dan 5 ppm $\left(\mathrm{Mn}_{1}\right)$. Kombinasi perlakuan diterapkan dalam satuan percobaan berupa ember plastik dengan media tanah. Data yang diperoleh di uji homogenitas ragam antar perlakuannya dengan Uji Bartlet dan kemenambahan data diuji dengan Uji Tukey. Jika asumsi terpenuhi, data dianalisis ragam dan dilanjutkan dengan uji analisis regresi. Semua pengujian dilakukan pada taraf $\alpha 0,05$ dan $\alpha 0,01$.

\section{Pelaksanaan Penelitian}

Benih yang digunakan adalah benih padi varietas Mekongga dengan viabilitas sebesar 95\%. Sebelum disemai benih direndam dalam air selama 24 jam. Selanjutnya, benih diperam menggunakan kain kasa selama 48 jam untuk menyerempakkan perkecambahan benih. Benih yang telah berkecambah kemudian disemai selama 21 hari.

Setelah bibit berumur 21 hari, bibit ditanam dalam ember percobaan. Penanaman dilakukan pada setiap ember yang berdiameter $28 \mathrm{~cm}$ dan berkapasitas $10 \mathrm{~kg}$ dengan jumlah 1 bibit per ember. Tanah yang digunakan pada percobaan ini adalah tanah Latosol Gedong Meneng, Bandar Lampung yang dilumpurkan sehingga menyerupai tanah sawah

Aplikasi Si dan Mn dilakukan sejak tanaman berumur 21 hari setelah tanam. Silika dan Mangan diaplikasikan sebanyak 3 kali dengan interval waktu 4 minggu setelah tanam sesuai dengan perlakuan. Aplikasi Si dilakukan dengan cara disemprotkan ke seluruh permukaan daun bagian bawah dengan menggunakan hand sprayer. Aplikasi larutan Si dan Mn dilakukan pada hari yang sama, namun Mn terlebih dahulu diaplikasikan pada daun tanaman padi. Hal ini dikarenakan $\mathrm{Si}$ bersifat melapisi jaringan daun tanaman sehingg apabila Si diaplikasikan terlebih dahulu dikhawatirkan Mn tidak dapat menembus kedalam jaringan daun tanaman karena telah terlapisi oleh Si.Pupuk dasar adalah $200 \mathrm{~kg}$ Urea/ha (1,5 g/ember), $150 \mathrm{~kg} \mathrm{SP}-18 / \mathrm{ha}(0,75$ g/ember), dan $150 \mathrm{~kg} \mathrm{KCl} / \mathrm{ha}(0,75 \mathrm{~g} / \mathrm{ember})$ yang diaplikasikan pada saat padi berumur 14 dan 42 hari setelah tanam.

\section{HASIL DAN PEMBAHASAN}

\section{Kondisi Pertumbuhan Tanaman}

Secara umum terjadi perbaikan pertumbuhan tanaman padi yang diberi perlakuan Silika dan Mangan. Pada Tabel 1 dapat kita lihat bahwa peningkatan konsentrasi Si dan pemberian Mn mempengaruhi pertumbuhan tanaman padi yang ditunjukkan oleh variabel tinggi tanaman, tingkat kehijauan daun, sudut anakan, jumlah anakan total, jumlah anakan produktif, dan bobot kering berangkasan (Tabel 3). Perbaikan pertumbuhan ini diharapkan juga akan memperbaiki mutu benih yang dihasilkan.

\section{Mutu Fisiologis Benih yang dihasilkan Daya berkecambah}

Pada konsentrasi 0 ppm Si tanpa pemberian Mn, daya berkecambah padi yang dihasilkan sebesar 93,7 \% dan meningkat sebesar $0,008 \%$ setiap penambahan konsentrasi 1 ppm Si. Pada konsentrasiSi 0 ppm dengan pemberian Mangan 5 ppm, daya berkecambah yang dihasilkan sebesar 94,4\% dan meningkat sebesar $0,03 \%$ pada setiap penambahan konsentrasi 1 ppm Si (Gambar 1).

\section{Keserempakan tumbuh benih}

Pada perlakuan Si 0 ppm tanpa pemberian $\mathrm{Mn}$, keserempakan tumbuh benih padi yang dihasilkan sebesar 93,16\% dan meningkat sebesar $0,01 \%$ setiap penambahan konsentrasi 1 ppm Si. Pada konsentrasi Si 0 ppm dengan pemberian Mangan $5 \mathrm{ppm}$, keserempakan tumbuh benihdidapat sebesar 94,4\% dan meningkat sebesar $0,03 \%$ pada setiap penambahan konsentrasi 1 ppm Si (Gambar 2).

\section{Bobot kering kecambah normal}

Pada perlakuan Si 0 ppm tanpa pemberian Mn, bobot kering kecambah normal yang dihasilkan sebesar 0,6 g dan meningkat sebesar 0,0002 g setiap penambahan konsentrasi 1 ppm Si. Pada konsentrasi Si 0 ppm dengan pemberian Mangan 5 ppm, bobot kering kecambah normal sebesar 0,6 $\mathrm{g}$ dan meningkat sebesar $0,0006 \mathrm{~g}$ pada setiap penambahan konsentrasi 1 ppm Si (Gambar 2).

Berdasarkan hasil penelitian, pemberian silika dan mangan dapat meningkatkan pertumbuhan tanaman padi. Hal ini dapat dilihat padapeubah tinggi tanaman, tingkat kehijauan daun, sudut anakan, jumlah anakan total, jumlah anakan produktif, dan bobot kering berangkasan yang menunjukkan pola peningkatan pertumbuhan sejalan dengan meningkatnya konsentrasi silika dan mangan yang diberikan (Tabel 1). 
Tabel 1. Rekapitulasi pengaruh peningkatan konsentrasi Silika dan penyemprotan Mangan terhadap pertumbuhan tanaman padi var. Mekongga

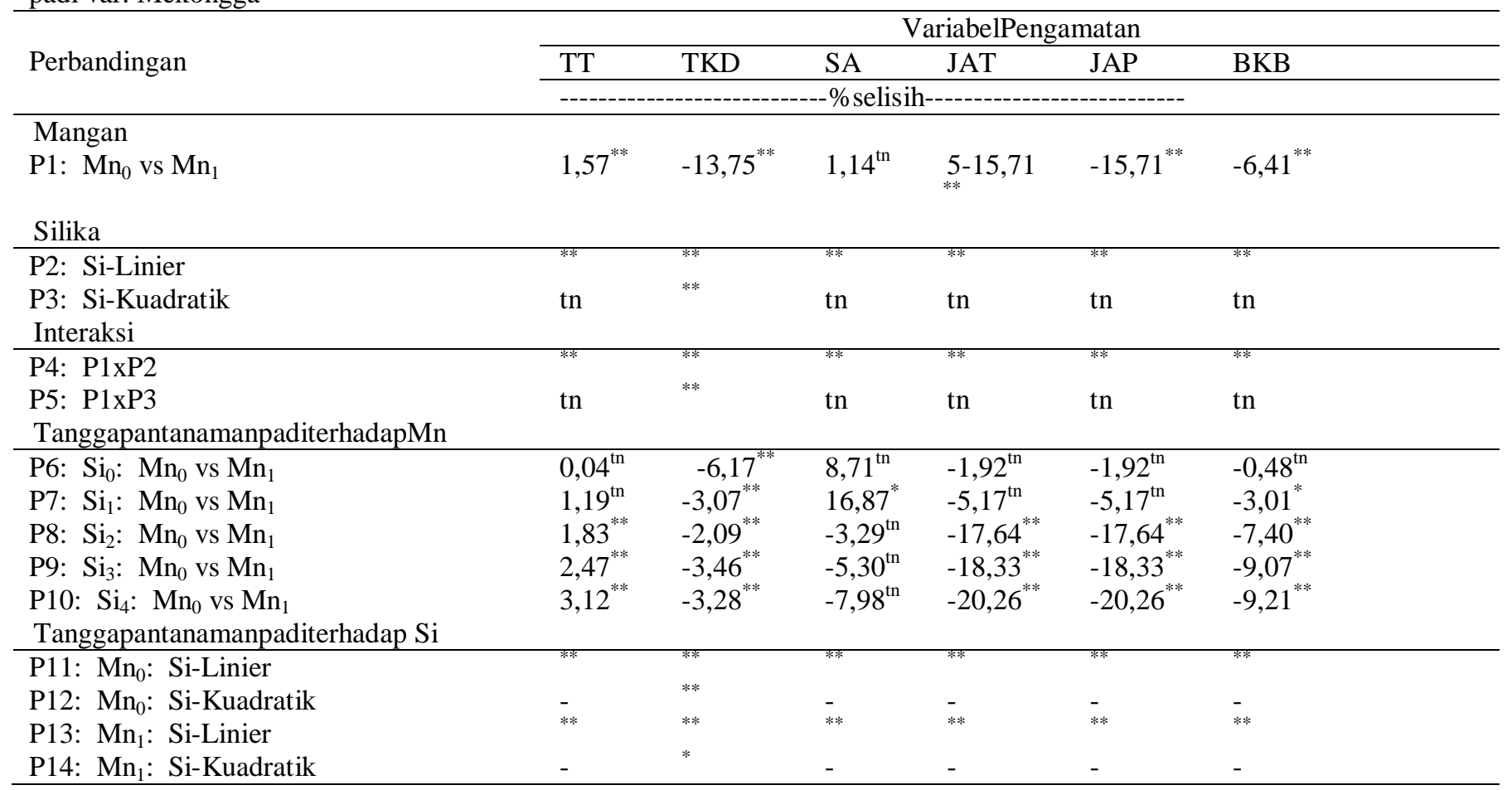

Sumber : Dewi (2014)

Keterangan : $\mathrm{Mn}_{0}=0$ ppm Mangan; $\mathrm{Mn}_{1}=5$ ppm Mangan; $\mathrm{Si}_{0}=0$ ppm Silika; $\mathrm{Si}_{1}=50$ ppm Silika; $\mathrm{Si}_{2}=00$ ppm Silika; $\mathrm{Si}_{3}$ $=150 \mathrm{ppm}$ Silika; $\mathrm{Si}_{4} \quad=200$ ppm Silika. TT= tinggi tanaman; $\mathrm{TKD}=$ tingkat kehijauan daun; $\mathrm{SA}=$ sudut anakan; JAT $=$ jumlah anakan total; $\mathrm{JAP}=$ jumlah anakan produktif; $\mathrm{BKB}=$ bobot kering berangkasan. $* *=$ berbeda pada $\alpha ; 1 \% ; *=$ berbeda pada $\alpha 5 \% ; \mathrm{tn}=$ tidak nyata.

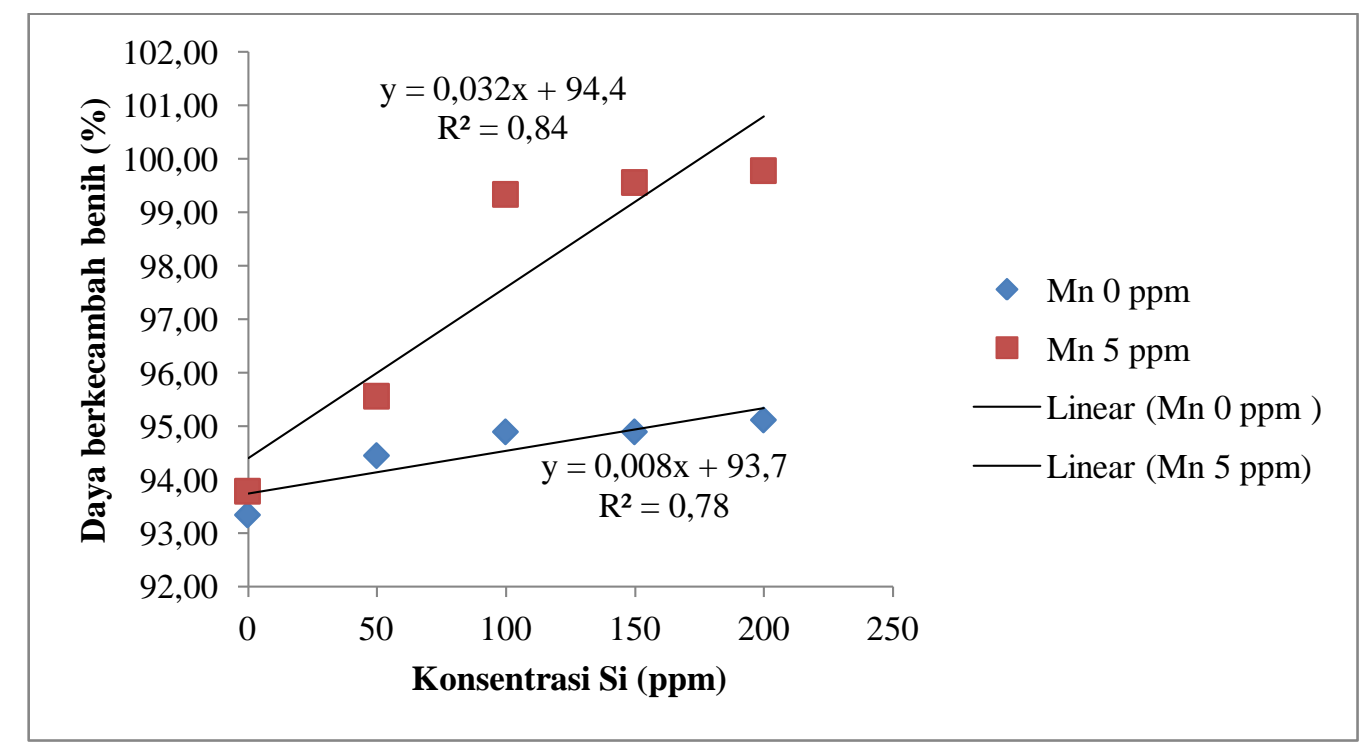

Gambar 1. Tanggapan daya berkecambah benih terhadap peningkatan konsentrasi Silika dengan pemberian Mn. 


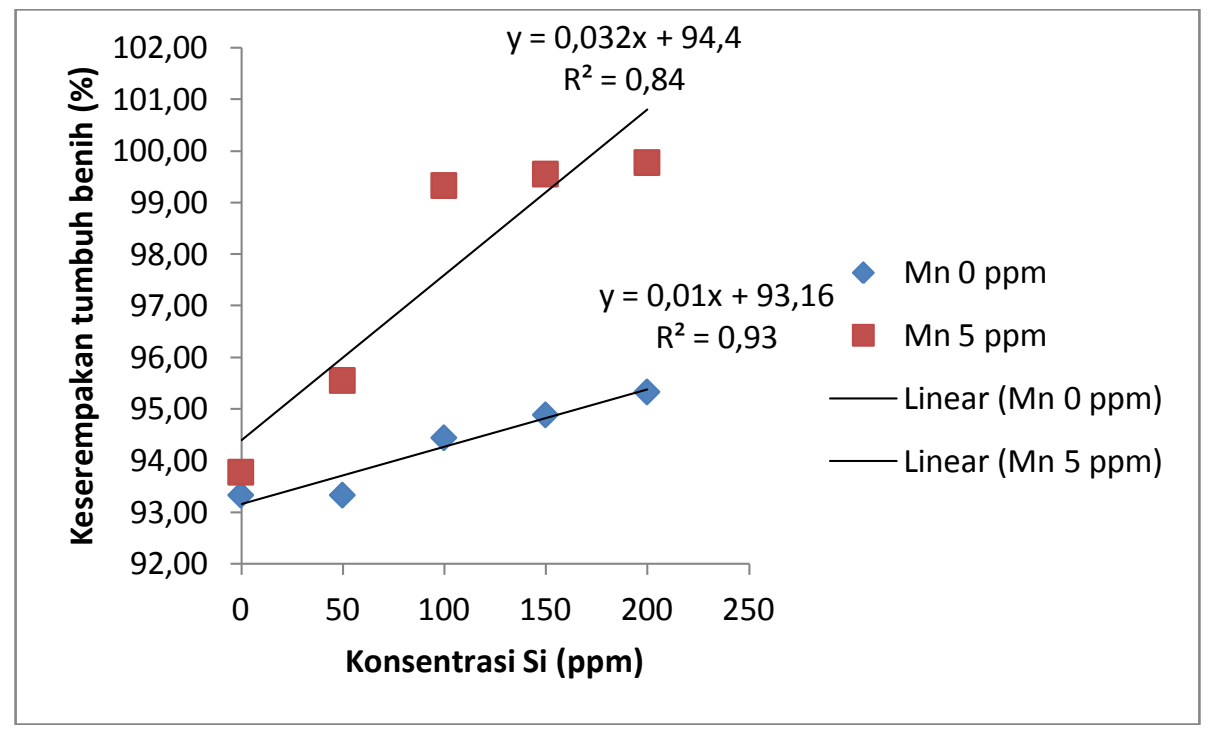

Gambar 2. Tanggapan keserempakan tumbuh benih terhadap peningkatan konsentrasi Silika dengan pemberian Mn pada tanaman padi

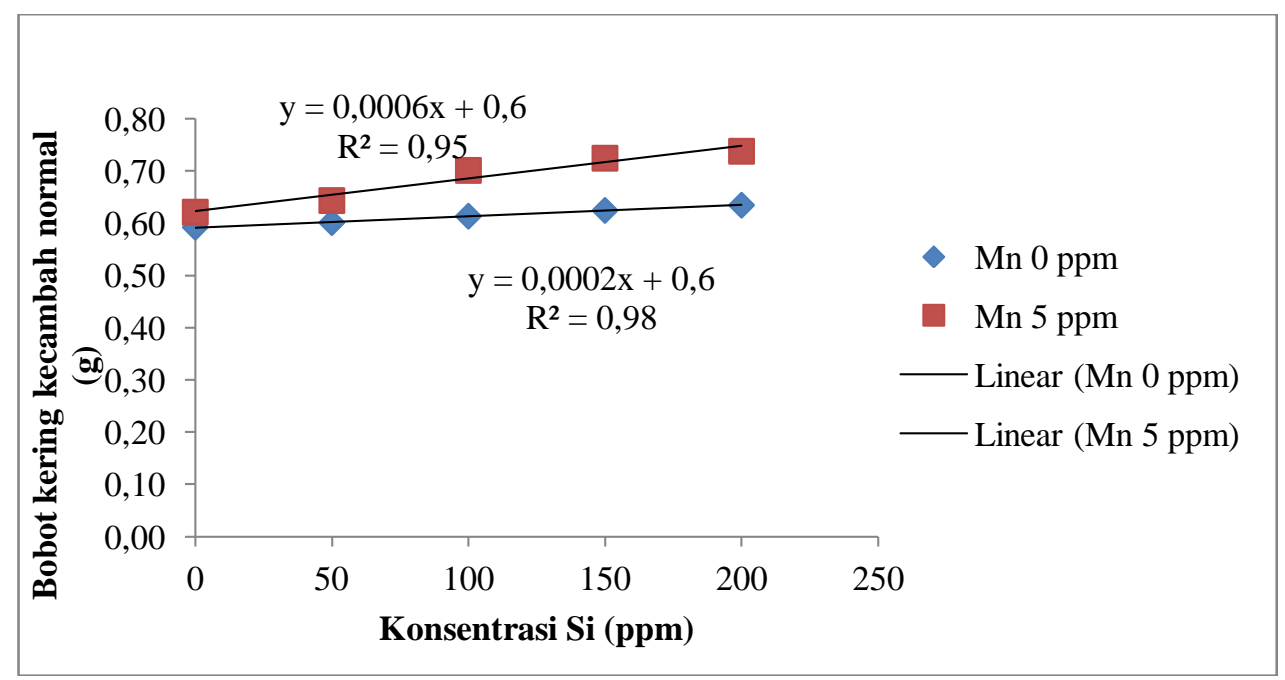

Gambar 3. Tanggapan bobot kering kecambah normal (g) terhadap peningkatan konsentrasi Silika dengan pemberian Mn

Menurut Makarimet al., (2007) melaporkan bahwa penambahan Si secara tidak langsung dapat meningkatkan efisiensi fotosintesis melalui peningkatan tinggi tanaman dan ketegakan sudut anakan. Junior et. al., (2010) menyimpulkan bahwa peningkatan tinggi tanaman dan semakin tegaknya sudut anakan padi terjadiakibat distribusi dan mobilisasi $\mathrm{Si}$ di dalam jaringan daun tanaman. Sedangkan Santos et.al., (2013), pemberian Mn sebesar 5 ppm juga mampu meningkatkan aktivitas fotosintesis

Meningkatnya kehijauan daun sebagai efek dari peningkatan konsentrasi $\mathrm{Si}$ dan pemberian $\mathrm{Mn}$ sebesar 5 ppm dapat meningkatkan jumlah anakan total, anakan produktif, dan bobot kering berangkasan. Meningkatnya konsentrasi Si yang disertai dengan pemberian Mn sebesar 5 sehingga konsentrasi klorofil yang dihasilkan semakin meningkat. Pada penelitian ini (yang telah dipublikasikan sebelumnya), peningkatan konsentrasi klorofil ditunjukkan oleh nilai SPAD yang terukur.Semakin tingginilai SPAD yang terukur semakin tinggi pula konsentrasi klorofil di dalam kloroplas yang mengindikasikan tingginya tingkat kehijauan daun tanaman padi yang berkontribusi terhadap pertumbuhan dan mutu benih yang dihasilkan.

ppm, senyawa organik yang disintesis oleh tanaman melalui proses fotosintesis akan semakin meningkat. Hasil sintesis ini antara lain berupa pati, lipid, dan protein yang diakumulasikan di dalam benih. Menurut Salisbury dan Ross (1995) mengungkapkan produk asimilat yang dihasilkan akan dimanfaatkan oleh tanaman padi untuk 
proses pembelahan dan penambahan ukuran sel di seluruh jaringan tanaman.

Perbaikan pertumbuhan tanaman juga diikuti dengan perbaikan mutu benih yang didapat. Fotosintat yang cukup akan disimpan oleh tanaman padi dalam bentuk cadangan makanan di dalam gabah. Bertambahnya pasokan fotosintat akan meningkatkan ukuran gabah. Bertambahnya ukuran gabah akan meningkatkan mutu benih yang dihasilkan. Pada penelitian ini pemberian silika dan mangan memberikan efek yang positif pada benih. Respons yang baik pada benih disebabkan oleh pertumbuhan tanaman yang juga disebabkan pemberian silika dan mangan. Datnoff(2005), silika juga berperan dalam memperbaiki ketidakseimbangan nutrisi, seperti defisiensi P.Pada tanaman gandum, pemupukan silika dengan dosis 300 dan 500 ppm tanah yang dikombinasikan dengan pemupukan $\mathrm{P} \quad 20 \mathrm{ppm}$ menghasilkan viabilitas dan vigor benih tertinggi (Toledo et al. 2011). Mengel \& Kirby (1982) dalam Syarief (2005) menyatakan bahwa benih tanaman yang dihasilkan dari tanaman yang mendapat cukup $\mathrm{P}$ akan memiliki viabilitas dan vigor yang tinggi karena pada benih yang cukup $P$ kandungan senyawa fitin akan lebih tinggi. Bewley \& Black (1994) menyatakan bahwa Phytic acid (myo-inositol hexaphosphate) adalah bentuk utama fosfat yang disimpan di dalam benih. Phytic acid di dalam benih tersebut terikat dengan element lain seperti $\mathrm{K}+, \mathrm{Mg} 2+$, dan $\mathrm{Ca} 2+$. Campuran phytic acid dan elemen tersebut disebut fitin (phytin atau phytate) dan menjadi sumber utama nutrisi pada benih. Proses pembongkaran fitin sebagai sumber energi untuk perkecambahan merupakan salah satu fungsi $\mathrm{P}$ dalam benih (tanaman).

\section{KESIMPULAN}

Peningkatan konsentrasi Si sampai 200 ppm yang disertai dengan pemberian $\mathrm{Mn}$ sebesar 5 ppm mampu meningkatkan mutu fisiologis tanaman pada variabel daya berkecambah, keserempakan tumbuh, dan bobot kering kecambah normal.

\section{DAFTAR PUSTAKA}

Agustina, L. 2011. Unsur Hara Mikro I (Fe, Mn, Zn. Cu, B, Mo, dan Cl) Manfaat Kebutuhan Kahat dan Keracunan Edisi Pertama. Program Pasca Sarjana Universitas Brawijaya. Malang.

Aref, F. 2012. Manganese, iron, and copper contents in leaves of maize plant (Zea mays L.) grown with different boron and zinc micronutrients. African Journal of Biotechnology. 11 (4): 896-903.

Balai Besar Penelitian Tanaman Padi. 2016. Direktori Padi Indonesia. Jakarta:Departemen Pertanian RI.

Badan Pusat Statistik. 2016. Produktivitas Padi Indonesia. .https://www.bps.go.id/site/resultTab. Diakses 13 Desember 2016.
Bewley JD, Black M. 1994. Seed: Physiology of Develpoment and Germination. Second edition. London \& New York: Plenum Press.

Datnoff LE. 2005. Silicon in the Life and Performance of Turfgrass. Applied Turfgrass Science. doi:10.1094/ATS-2005-0914-01-RV.

Dewi, M, M. 2014. Pengaruh aplikasi silika dan mangan padapertumbuhan dan produksi padi. Skripsi Sarjana, Fakultas Pertanian Universitas Lampung. Bandar Lampung.

Humphrise, J. M. 2006. Handbook of Plant Nutrition. Edited by Allen V. Barker and David J. Pilbeam.CRC Press. New York. p $351-66$.

Junior, L. A. Z., R. L.F. Fontes, J. C. L. Neves, G. H. Korndörfer and V. T. de Ávila. 2010. Rice grown in nutrient solution with doses of manganese and silicon. R. Bras. Ci. Solo. 34: $1629-39$.

Ma JF, Nishimura Kazuo, Takahashi E. 1989. Effect of silicon on the growth of rice plant at different growth stages. Soil Sci Plant Nutr 35(3):347-356.

Ma JF, Takahashi. 1990. Effect of silicon on the growth and phosphorus uptake of rice. Plant Soil 126:115119.ANFENG MA and EIICHI TAKAHASHI

Mauad M, Crusciol CAC, Filho HG,Corrêa JC. 2003. Nitrogen and silicon fertilization of upland rice. Scientia Agricola 60(4):761-765.

Makarim, A. K., E. Suhartatik, dan A. Kartohardjono. 2007. Silikon: Hara penting pada sistem produksi padi. Iptek Tanaman Pangan. 2 (2): 195-204.

Ranganathan S, Suvarchala V. Rajesh YBRD, Prasad MS, Padmakumari AP, and Voleti SR. 2006. Effects of silicon sources on its deposition, chlorophyll content, and disease and pest resistance in rice. Biologia Plantarum 50 (4): 713-716.

Salisbury, F.B. dan C.W. Ross. 1995. Fisiologi Tumbuhan III. Diterjemahkan oleh Lukman, D.R. dan Sumaryono dari buku Plant Physiology. Penerbit ITB. Bandung. $173 \mathrm{hlm}$.

Santos, E.F., B. J. Zanchim, A. G. de Campos, R. F. Garrone, and J. L. Junior. 2013. Photosynthesis rate, chlorophyll content, and initial development of physicnut without micronutrient fertilization. $R$. Bras. Ci. Solo.(37): $1334-42$.

Syarif AA. 2005. Adaptasi dan ketenggangan genotipe padi terhadap defisiensi fosfor di tanah sawah [Disertasi]. Sekolah Pascasarjana, Institut Pertanian Bogor.

Toledo MZ, Garcia RA, Merlin A, Fernandes, DM. 2011. Seed germination and seedling development of white oat affected by silicon and phosphorus fertilization. Sci. Agric 68 (1):18-23.

Yukamgo, E.dan N. W.Yuwono. 2007. Peran silika sebagai unsur hara bermanfaat pada tanaman tebu. Jurnal Ilmu Tanah dan Lingkungan.7 (2): 103-16. 